\title{
AKIBAT HUKUM TERHADAP PEMBELIAN SUATU BARANG SECARA ONLINE
}

\author{
I Gusti Bagus Guna Mahayana, Anak Agung Sagung Laksmi Dewi, Luh Putu Suryani \\ Fakultas Hukum Universitas Warmadewa, Denpasar-Bali, Indonesia
}

\begin{abstract}
Abstrak
Permasalahan yang berkaitan mengenai urusan pelanggan akan menjadi suatu hal yang selalu menjadi sorotan yang sangat panjang kemudian pihak yang kalah selalu pada sisi pelangggan. Hak yang sudah dijanjikan pelaku usaha yang mengedepankan kualitas tidak sesuai harapan pelanggan. Kekurangan pelanggan mengenai dasar hukum dan apa yang seharusnya menjadi haknya sangat lemah, hal inilah yang digunakan kesempatan untuk memperoleh hasil yang lebih banyak dan tidak menjalakan prosedur yang seharusnya menjadi kewajiban pengusaha. Sehingga banyak pelanggaran yang terjadi bahkan sampai melanggar hukum dan merugikan pelanggan. Penelitian ini bertujuan untuk mengkaji pengaturan hukum tentang pembelian barang secara online dan menelaah sanksi pidana terhadap objek online yang melakukan penipuan. Penelitian ini menggunakan metode normatif dikarenakan masih terdapat norma yang kabur, dengan pendekatan Perundang-undangan dan konseptual. Adapun data yang digunakan yaitu dari data kepustakaan yang dikumpulkan melalui penelitian literatur dan mempelajari ulang peraturan Perundang-undangan. Setelah data terkumpul selanjutnya dianalisis dengan analisis data kualitatif deskriptif. Hasil penelitian menunjukkan bahwa Pengaturan hukum terhadap suatu perbuatan pelaku usaha kepada konsumen dalam jual beli online termasuk suatu perbuatan yang dilarang bagi pelaku usaha dengan memenuhi unsur-unsur tertentu sesuai dengan ketentuan peraturan yang ada dan telah dimuat dalam Undang-undang KUHP Tahun 2015 pengaturan pasalnya terdapat dalam 6 pasal yaitu mulai dari Pasal 613 sampai dengan Pasal 618, selanjutnay sanksi yang diterapkan dapat berupa sanksi administratif maupun sanksi kurungan.
\end{abstract}

Kata Kunci: Jual Bel Online, Sanksi Pidana, Tindak Penggelapan

\begin{abstract}
Problems related to customer affairs will be something that is always in the spotlight for a very long time then the losing party is always on the customer side. The rights that have been promised by business actors who prioritize quality do not match customer expectations. The lack of customers regarding the legal basis and what should be their rights is very weak, this is the opportunity to get more results and do not carry out procedures that should be the obligation of entrepreneurs. So that many violations occur even to the point of violating the law and harming customers. This study aims to examine the legal arrangements regarding the purchase of goods online and examine criminal sanctions against online objects that commit fraud. This study uses a normative method because there are still vague norms, with a legislative and conceptual approach. The data used is from library data collected through literature research and reviewing the legislation. After the data was collected, it was then analyzed by descriptive qualitative data analysis. The results of the study indicate that the legal regulation of an act of business actors to consumers in online buying and selling includes an act that is prohibited for business actors by fulfilling certain elements in accordance with existing regulatory provisions and has been contained in the 2015 Criminal Code Law. in 6 articles, starting from Article 613 to Article 618, then the sanctions applied can be in the form of administrative sanctions or imprisonment.
\end{abstract}

Keywords: Buying and Selling Online, Criminal Sanctions, Embezzlement

\section{PENDAHULUAN}

Indonesia adalah Negara hukum, sebagaimana telah ditegaskan dalam ketentuan Pasal 1 ayat (3) UUD NRI Tahun 1945. Negara hukum pada dasarnya bertujuan untuk memberikan perlindungan hukum bagi rakyatnya (Arliman. S, 2019). Dimana yang menjadi maksud dari melindungi secara, keamanan dan kesejahteraan rakyatnya sehingga tercipta suatu suasana yang kondusif dalam system hukum (Tutik, 2006).

Perkembangan zaman ditandai dengan kemajuan teknologi disebut dengan istilah lain dari Globalisasi. Arus globalisasi yang sedang dihadapi, mengakibatkan persoalan hampir seluruh bidang 
meliputi bidang budaya, sosial, politik, ekonomi, ilmu pengetahuan, dan teknologi sehingga terjadi perubahan pola pikir yang sangat drastis dalam keseharian. Sifat hukum yang bersifat stagnan, melainkan harus bersifat dinamis, serta selalu diadakan perubahan sejalan dengan perkembangan zaman dan persoalan kehidupan sosial dalam masyarakat (Hendro Setyo Wahyudi, 2014).

Transaksi pertukaran barang adalah perjanjian yang telah disepakati dimana diatur dalam KUHPerdata, sedangkan E-commerce pada dasarnya merupakan jenis transaksi pertukaran baru seperti media social dan jaringan yang telah lahir dari ide perkembangan jaman. Kesepakatan dari semua stakeholder yang sudah dirundingkan yang sudah mengikat baik tertulis maupun lisan dengan sudah ada konsekuensi hukumnya masing-masing (Rongiyati, 2019).

Dalam transaksi online yang berkembang pada era ini ide dari pelaku usaha yang sangat terus berkembang sngat mendorong semua sistem yang sudah ada pelanggan disajikan transaksi yang gampang dan sederhahana namun dilain sisi ada pihak-pihak yang memanfaatkan celah celah yang ada untuk melakukan penggelapan sehinggga menyebabkan kerugian kepada pelanggan. Dimana terlihat jelas masalah yang akan dihadapi, namun terkadang dalam sisi lain kita terlau mengabaikan dasar-dasar hukum.

Selain itu banyak terjadi kasus salah kirim barang, padahal yang diperdagankan adalah barang kelas 1 menjadi barang kelas 2 atau barang yang diwaktu promosikan terlihat bagus tapi setelah dikirim menjadi barang cacat atau tidak layak pakai. Permasalahan atau kendala seperti inilah biasanya menyebakan suatu masalah yang berbenturan dengan norma hukum yang biasanya merugikan pelanggan selaku penikmat dari sajian yang disedikan pengusaha. Fenomena yang berkembang sangat memperburuk transaksi online yang biasa mengakibatkan kerugian yang sangat besar. Selain itu, pada kegiatan jual-beli yang dilakukan melalui online antara penjual dan pembeli, terdapat akibat-akibat hukum yang diperoleh apabila terjadi segala bentuk tindak penyimpangan yang dilakukan oleh pihak-pihak tertentu terkait pembelian suatu barang maupun jasa dalam online.

Selain itu, pada transaksi yang dilakukan melalui online antara pengusaha dan pelanggan, terdapat akibat-akibat hukum yang diperoleh apabila terjadi segala bentuk tindak penyimpangan yang dilakukan oleh pihak-pihak tertentu terkait pembelian suatu barang maupun jasa dalam online. Perdagangan melalui e-commerce selalu meningkat jumlahnya. Sebelumnya (Putra, 2014) \& (Wulandari, 2018) Mengkaji Perlindungan Hukum bagi Konsumen terhadap Transaksi Jual Beli ECommerce. Konsumen yang menjadi korban transaski jual beli online mendapatkan perlindungan terhadap hak-hak konsumen, diatur dalam pasal 4 Undang-undang Nomor 8 Tahun 1999 tentang Perlindungan Konsumen (Nugrah \& Mukhtar, 2015). Sekalipun pakar hukum sebelumnya sudah banyak mengkaji tentang kasus jual beli melalui online, namun smpai saat ini diketahui masih banyak kasusu penipuan lewat sosial media terutam dalam pemasaran. Oleh karena itu penili ingin melakukan penelitian dari kajian yang berbeda dengan tujuan untuk mengkaji pengaturan hukum tentang pembelian barang secara online dan menelaah sanksi pidana terhadap objek online yang melakukan penipuan.

\section{METODE PENELITIAN}

Penelitian ini didesain dengan metode normatif dengan pendekatan perundang-undangan dan konseptual. Adapun data yang digunakan yaitu data primer dan sekunder. Data primer diperoleh dari data kepustakaan yang dikumpulkan melalui penelitian literatur dan mempelajari ulang peraturan Perundang-undangan. Data sekunder yaitu data teori hukum sebelumnya yang terkait tentan masalah yang sedang diteliti yang diperoleh melalui literatur dan jurnal ilmiah. Setelah data terkumpul selanjutnya dianalisis dengan analisis data kualitatif deskriptif.

\section{HASIL DAN PEMBAHASAN}

\section{Pengaturan Hukum tentang Pembelian Barang Secara Online}

Sebagai landasan di dalam memecahkan permasalahan dalam penelitian ini, maka penulis akan berpijak kepada ketentuan perundang-undangan yang berlaku dan disamping itu pula akan dipakai sebagai pegangan adalah pendapat-pendapat dari para sarjana terkait dengan permasalahan tersebut di atas. Pada ketentuan norma hukum, terdapat suatu ketentuan peraturan yang khusus mengatur mengenai sanksi-sanksi pidana terkait perilaku masyarakat yang tidak berdasar pada norma hukum yang ada, disebut dengan hukum pidana. Hukum pidana adalah bagian dari hukum yang paling sulit. Ruang lingkup pengertian hukum pidana dapat bersifat luas dan dapat pula bersifat sempit. Hukum 
pidana sebagai bentuk hukum yang "memaksakan" sanksi dalam pelanggaran atau perbuatan kejahatan (Prodjodikoro, 1989). Hukum pidana dapat dibedakan menjadi ilmu hukum pidana normatif, ilmu hukum pidana berdasarkan kenyataan (fakta), filsafat hukum pidana yang bukan ditujukan pada diri sendiri tetapi ditujukan untuk menegakkan tertib hukum, melindungi masyarakat hukum.

Adapun bentuk-bentuk akibat hukum yang dapat diperoleh pada saat pembelian melalui online, salah satunya yaitu adanya suatu penggelapan yang diperoleh oleh konsumen pada saat pembelian dari online, selain itu ada penipuan berupa seputaran informasi-informasi yang dianggap tidak akurat atau dapat dikatakan suatu informasi yang dapat meyakini pembeli untuk tertarik membeli suatu produk yang disediakan melalui online (Kusuma Putra, 2018).

Barang adalah produk konsumsi nyata, artikel, komoditas yang ditawarkan oleh perusahaan kepada pelanggan dengan imbalan uang serta memiliki karakteristik fisik yaitu bentuk, penampilan, ukuran, berat dan lain-lainnya. Barang mampu memuaskan keinginan manusia dengan memberikan utilitas atau kegunaannya untuk memenuhi kebutuhan pelanggan. Barang atau Goods pada dasarnya dapat dipakai sekali saja ataupun ada yang bisa dipakai untuk berulang kali. Adapun pengertian dari bisnis online segala transaksi yang dilakuakan lewat media social baik itu web, facebook, Instagram dan bebagai macam sarana yang disediakan dalam dunia maya. Dalam hal inilah biasanya akan sangat menyulitkan karena semua tersaji secara maya maka dari itu Pengaturan hukum terhadap suatu perbuatan pelaku usaha kepada konsumen dalam jual beli online termasuk suatu perbuatan yang dilarang bagi pelaku usaha, dimana diatur dalam Bab IV pasal 8 hingga pasal 17 Undang-undang Nomer 8 Tahun 1999 tentang Perlindungan Konsumen, ketentuan-ketentuan tersebut dapat dibagi dalam tiga kelompok yaitu larangan bagi pelaku usaha dalam kegiatan produksi, larangan bagi pelaku usaha dalam kegiatan pemasaran, dan larangan bagi pelaku usaha periklanan. Larangan bagi pelaku usaha dalam kegiatan produksi. Kelompok larangan yang pertama adalah larangan bagi pelaku usaha dalam kegiatan produksi yang diatur dalam pasal 8 UU Perlindungan Konsumen.

Seperti dalam kasus yang dialami oleh beni simorangkir, remaja yang melihat ungggahan sebuah akun online shop yang menjual pakaian, langsung tertarik dengan harga yang sangat jauh terjangkau daripada dengan harga pakaian ditoko biasa, dengan perbandingan Rp. 75.000,-/buah, maka beni hendak membeli pakaian tersebut, namun setelah melakukan transaksi dengan online oleh pemilik online shop, barang yang dibeli oleh Beni tak kunjung datang. Sehingga dari sini sudah termasuk penipuan.

Konsumen dan pelaku usaha ibarat sekeping mata uang dengan sisi yang berbeda. Konsumen membutuhkan produk (barang/jasa) pelaku usaha, tetapi kegiatan pelaku usaha itu akan mubadzir apabila tidak ada konsumen yang membeli hasil usahanya. Karena itu keseimbangan dalam segala segi, menyangkut kepentingan dari dua belah pihak ini merupakan hal yang ideal yang harus diperhitungkan. Konsumen sebagai penikmat barang atau jasa seringkali diabaikan hak-haknya oleh para pelaku usaha, faktor yang mempengaruhi hal tersebut diantaranya faktor pelaku usaha yang menganggap bahwa konsumen mudah dieksploitasi dan dipengaruhi untuk mengkonsumsi segala bentuk barang atau jasa yang ditawarkan.

\section{Sanksi Pidana terhadap Ojek Online yang Melakukan}

Tujuan untuk diadakan pidana dan perkembangannya di Indonesia dimaksudkan sebagai salah satu usaha untuk mencegah atau menanggulangi kejahatan dimana hampir semua Negara menggunakan aturan pidana untuk mencegah dan memberantas kejahatan. Tindak Pidana penggelapan dalam Rancangan Undang-undang KUHP Tahun 2015. Kejahatan penggelapan dapat disebabkan oleh beberapa factor pendukung, seperti yang diketahui bahwa penggelapan adalah termasuk di dalam bagian kejahatan yang diatur di dalam KUHP (buku dua) ketentuan pada Pasal 372 sampai dengan Pasal 377. Penggelapan termasuk di dalam jenis kejahatan terhadap harta benda.

Kejahatan yang terjadi di dalam kehidupan bemasyarakat menjadi fenomena yang terus menjadi sorotan. Berbicara tentang timbulnya penggelapan maka tidak terlepas dari sebab-sebab timbulnya kejahatan itu sendiri dimana hal ini dikarenakan bahwa penggelapan seperti yang diuraikan sebelumnya adalah merupakan bagian dari kejahatan yang diatur di dalam KUHP. Faktor-faktor yang menyebabkan terjadinya tindak pidana penggelapan berdasarkan data yang diperoleh secara umum dimana pertama, mentalitas yang buruk merupakan salah satu faktor yang menimbulkan terjadinya tindak pidana penggelapan (Gunadi \& Efendi, 2011). Pegawai yang tidak kuat mentalnya maka akan 
mudah terpengaruh untuk melakukan tindakan yang sesuai dengan harkat dan martabat pegawai sebagai petugas. Sebaliknya pegawai yang bermental kuat tidak dapat dipengaruhi oleh adanya kesempatan atau peluang melakukan penggelapan.

Adapun contoh kasus amtara lain seorang ojek online beranisial A sedang mengantarkan suatu barang ke alamat tujuan penerima barang, barang yang telah dijanjikan berjumlah tiga barang sedangkan diperjalanan tanpa sengaja A menaruh barang penerima di tempat tinggalnya untuk dapat dimiliki tanpa adanya ijin dari penerima barang tersebut, maka dapat dikatakan seorang ojek online tersebut terlibat dalam suatu tindak pidana penggelapan. Pengertian Tindak Pidana Penggelapan diatur dalam Pasal 372 KUHP, pasal 372 KUHP yang berbunyi Barang siapa dengan sengaja mimiliki dengan melawan hak suatu benda yang sama sekali atau sebagiannya termasuk kepunyaan orang lain dan benda itu ada dalam tangannya bukan karena kejahatan, dihukum karena penggelapan dengan hukuman penjara selama-lamanya empat tahun atau denda sebanyak Rp. 900, menurut Andi Hamzah bagian inti delik atau tindak pidana penggelapan sebagaimana diatur dalam Pasal 372 KUHPidana adalah sebagai berikut pertama sengaja, kedua melawan hukum, ketiga memiliki suatu barang, keempat yang selanjutnya atau kepunyaan orang lain, kelima yang ada dalam kekuasaannya bukan karena kejahatan. Ketentuan Pasal 373 KUHPidana mengatur delik penggelapan ringan jika barang itu bukan termasuk dalam nilainya tidak lebih dari dua ratus lima puluh rupiah.

\section{SIMPULAN DAN SARAN}

\section{Simpulan}

Hasil penelitian menunjukkan bahwa Pengaturan hukum terhadap suatu perbuatan pelaku usaha kepada konsumen dalam jual beli online termasuk suatu perbuatan yang dilarang bagi pelaku usaha dengan memenuhi unsur-unsur tertentu sesuai dengan ketentuan peraturan yang ada dan telah dimuat dalam Undang-undang KUHP Tahun 2015 pengaturan pasalnya terdapat dalam 6 pasal yaitu mulai dari Pasal 613 sampai dengan Pasal 618, selanjutnya sanksi yang diterapkan dapat berupa sanksi administratif maupun sanksi kurungan. Akibat hukum terhadap ojek online yang melakukan tindak pidana penggelapan dimana sebagaimana diatur dalam suatu Rancangan Undang-undang KUHP Tahun 2015 pengaturan pasalnya terdapat dalam 6 pasal yaitu mulai dari Pasal 613 sampai dengan Pasal 618. Unsur-unsur Tindak Pidana Penggelapan berdasarkan ketentuan Pasal 372 KUHP tindak pidana dalam bentuk pokok mempunyai unsur-unsur objektif yang terdiri dari mengaku sebagai milik sendiri, sesuatu, seluruhnya atau sebagian adalah milik orang lain, yang berada dalam kekuasaannya bukan karena kejahatan, unsur subjektif yang terdiri dari unsur kesengajaan dan unsur melawan hukum. Sedangkan untuk sanksi yang diterapkan dapat berupa sanksi administratif maupun sanksi kurungan.

\section{Saran}

Terkait Simpulan dari pemaparan diatas, adapun saran yang diberikan yaitu Bagi pemerintah dalam hal ini sebagai pejabat berwenang, maka wajib halnya untuk mengkaji ulang tentang adanya ketentuan peraturan pada pasal dalam KUHP terkait sanksi pidana, agar segala sesuatu bentuk tindak pidana penggelapan dapat teratasi tanpa adanya suatu kendala dan setidaknya dapat terminimalisir, selanjutnya Bagi masyarakatdan prodeusen sebagai konsumen hendaknya berhati-hati dalam memilih suatu produk dalam situs jual beli online, dikarenakan banyak terdapat akun-akun yang memasarkan produk-produk yang dapat merugikan konsumen dengan jumlah harga yang terbilang cukup murah.

\section{DAFTAR PUSTAKA}

Arliman. S, L. (2019). Mewujudkan Penegakan Hukum Yang Baik Di Negara Hukum Indonesia. Dialogia Iuridica: Jurnal Hukum Bisnis Dan Investasi, 11(1), 1-20.

Gunadi, I., \& Efendi, J. (2011). Hukum Pidana. Jakarta. Prenadamedia Group

Hendro Setyo Wahyudi, M. P. S. (2014). Teknologi dan Kehidupan Masyarakat. Jurnal Analisa Sosiologi, 3(1), 13-24.

Kusuma Putra, I. C. (2018). Perlindungan Hukum Notaris Terhadap Perjanjian Perikatan Jual Beli yang Diikuti dengan Adanya Pengakuan Hutang. Jurnal Lex Renaissance, 3(2), 377-390.

Nugrah, R. adi, \& Mukhtar, J. (2015). Perlindungan hukum terhadap Konsumen dalam Transaksi Online. Jurnal Serambi Hukum, 8(2), 91-102.

Prodjodikoro, W. (1989). Arns- Asas Hukum Pidana. Lombok: PT. Erecos. 
Putra, S. (2014). Perlindungan Hukum Terhadap Konsumen dalam Transaksi Jual-Beli Melalui ECommerce. Jurnal Ilmu Hukum, 4(2), 287-309.

Rongiyati, S. (2019). Pelindungan Konsumen dalam Transaksi Dagang Melalui Sistem Elektronik (Consumer Protection in E-Commerce). Negara Hukum, 10(1), 1-25.

Tutik, T. T. (2006). Pengantar Hukum Perdata di Indonesia. Prestasi Pustaka Publiser.

Wulandari, Y. S. (2018). Perlindungan Hukum bagi Konsumen terhadap Transaksi Jual Beli ECommerce. Jurnal Ilmu Hukum, 2(2), 199-210. 